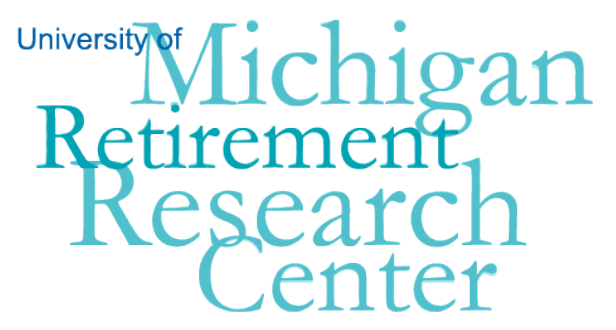

Working Paper WP 2013-291

\title{
Older Adult Debt and Financial Frailty
}

\author{
Annamaria Lusardi and Olivia S. Mitchell
}

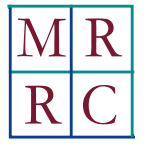

Project \#: UM13-09 



\title{
Older Adult Debt and Financial Frailty
}

\author{
Annamaria Lusardi \\ George Washington University School of Business
}

Olivia S. Mitchell

Wharton School, University of Pennsylvania

September 2013

\author{
Michigan Retirement Research Center \\ University of Michigan \\ P.O. Box 1248 \\ Ann Arbor, MI 48104 \\ www.mrrc.isr.umich.edu \\ (734) 615-0422
}

\section{Acknowledgements}

This work was supported by a grant from the Social Security Administration through the Michigan Retirement Research Center (Grant \# 5 RRC08098401-05-00). The findings and conclusions expressed are solely those of the author and do not represent the views of the Social Security Administration, any agency of the Federal government, or the Michigan Retirement Research Center.

\section{Regents of the University of Michigan}

Mark J. Bernstein, Ann Arbor; Julia Donovan Darlow, Ann Arbor; Laurence B. Deitch, Bloomfield Hills; Shauna Ryder Diggs, Grosse Pointe; Denise Ilitch, Bingham Farms; Andrea Fischer Newman, Ann Arbor; Andrew C.

Richner, Grosse Pointe Park ; Katherine E. White, Ann Arbor; Mary Sue Coleman, ex officio 


\title{
Older Adult Debt and Financial Frailty
}

\begin{abstract}
Of particular interest in the present economic environment is whether access to credit is changing peoples' indebtedness over time, particularly as they approach retirement. This project analyzes older individuals' debt, debt management practices, and financial fragility using data from the Health and Retirement Study (HRS) and the National Financial Capability Study (NFCS). Specifically, we examine three different cohorts (individuals age 56-61) in different time periods, 1992, 2002 and 2008, in the HRS to evaluate cross-cohort changes in debt over time. We also draw on recent data from the National Financial Capability Study (NFCS) which provides detailed information on how families manage their debt. Our goal is to assess how wealth and debt among older persons has evolved over time, along with the potential consequences for retirement security. We find that more recent cohorts have taken on more debt and face more financial insecurity, mostly due to having purchased more expensive homes with smaller down payments. In addition, Baby Boomers are more likely to have engaged in expensive borrowing practices. Factors associated with better debt outcomes include having higher income, more education, and greater financial literacy; those associated with financial fragility include having more children and experiencing unexpected large income declines. Thus, shocks do play a role in the accumulation of debt close to retirement. But it is not enough to have resources, people also need the capacity to manage those resources if they are to stay out of debt as they head into retirement.
\end{abstract}

\section{Citation}

Lusardi, Annamaria, and Olivia S. Mitchell (2013). “Older Adult Debt and Financial Frailty.” Ann Arbor MI: University of Michigan Retirement Research Center (MRRC) Working Paper, WP 2013-291. http://www.mrrc.isr.umich.edu/publications/papers/pdf/wp291.pdf

\section{Authors’ Acknowledgements}

The research was supported by a grant from the US Social Security Administration (SSA) to the Michigan Retirement Research Center (MRRC) as part of the Retirement Research Consortium (RRC). Support was also provided by the Pension Research Council/Boettner Center of the Wharton School at the University of Pennsylvania. We thank Barbara Butrica and participants at the 15th Annual Joint Conference of the Retirement Research Consortium for comments and Carlo de Bassa Scheresberg, Ana Gazmuri, and Yong Yu for research assistance. The findings and conclusions are solely those of the authors and do not represent the views of SSA, any agency of the Federal Government, the MRRC, or any other institutions with which the authors are affiliated. @ 2013 Lusardi and Mitchell. 


\section{Introduction}

Access to credit has become much easier and opportunities to borrow have expanded greatly. Yet recent research has shown that many individuals lack the financial knowhow to manage the complex new financial products increasingly available in the financial marketplace. ${ }^{1}$ How people borrow and manage debt has become of concern, given the evidence on overindebtedness documented in recent papers. ${ }^{2}$ As a consequence, older persons today may be much more likely to enter retirement age in debt compared to decades past. Our goals in the present paper are to evaluate empirically the factors associated with older individuals' debt and debt management practices, and whether (and how) these patterns have changed significantly over time. Accordingly, we evaluate older individuals' debt patterns using the Health and Retirement Study (HRS) and the National Financial Capability Study (NFCS). Using the HRS, we compare three different cohorts of people on the verge of retirement (age 56-61) at three different time periods: 1992, 2002 and 2008. We draw conclusions about the determinants of debt then assess how debt among older persons has evolved, and we discuss the potential consequences of our findings regarding indebtedness on the verge of retirement. ${ }^{3}$ Using the 2009 and 2012 National Financial Capability Study (NFCS), we explore detailed information on how families manage their debt.

Our focus on debt is important for several reasons. First, debt generally rises at interest rates higher than those which can be earned generally on assets. For this reason, debt management is critical for those seeking to manage their retirement assets. Second, not only do families have greater opportunities to borrow to buy a home and access home equity lines of credit, but also they need lower down payments needed to buy a home. Additionally, as subprime mortgages proliferated, credit became increasingly accessible to consumers with low credit scores, little income, and few assets. Consumer credit, such as credit card borrowing, has also become more accessible, and this type of unsecured borrowing has increased over time (Mottola, 2013). Third, in many states, alternative financial services have proliferated including payday loans, pawn shops, auto title loans, tax refund loans, and rent-to-own shops (Lusardi and

\footnotetext{
${ }^{1}$ See for instance Lusardi and Mitchell (2007, 2008, 2011a, b, c, forthcoming) and Lusardi, Mitchell, and Curto, 2012)

${ }^{2}$ Lusardi and Tufano (2009a,b), Lusardi and De Bassa Scheresberg, (2013), and the review by Lusardi and Mitchell (2014).

${ }^{3}$ Our prior work examined saving and asset building among those 50+ (Lusardi and Mitchell, 2007, 2011a).
} 
de Bassa, 2013). Fourth, a focus on debt may help to identify financially fragile families who may be sensitive to shocks and not be able to afford a comfortable retirement. Last, the recent financial and economic crisis was largely driven by borrowing behavior, so understanding debt may be informative to help avoid a repeat of past errors.

\section{Prior Literature}

Many have expressed concern that Americans approaching retirement face worrisome levels of debt. ${ }^{4}$ Data show that people do carry debt until late in the life cycle: over half (55\%) of the American population age 55-64 carries a home mortgage, and about the same fraction (50\%) has credit card debt (Bucks et al., 2009). Moreover, among people age 65-74, almost half had mortgages or other loans on their primary residences, over a third held credit card debt, a quarter had installment loans; in this age group, two-thirds held some form of debt. Furthermore, managing debt and other financial matters is problematic for many in the older population (FINRA, 2006, 2007). For instance, research has revealed a U-shaped age pattern of quality of financial decision-making regarding 10 financial areas including credit card balance transfers; home equity loans and lines of credit; auto loans; credit card interest rates; mortgages; smallbusiness credit cards; credit card late-payment fees; credit card over-limit fees; and credit card cash-advance fees (Agarwal et al. 2009). Fees and interest paid are lowest in the early 50s and rise thereafter; moreover, older individuals pay some of the highest costs for these services. Moreover, debt can have consequences when workers retire or start claiming their Social Security benefits (Butrica and Karamcheva, 2013).

Of late, there has also been an increase in the proportion of older Americans filing for bankruptcy. Pottow (2012) concluded that the age 65+ demographic is the fastest-growing in terms of bankruptcy filings, which were 2\% in 1991 and rose to more than three times that rate by 2007. Credit card interest and fees were the most-cited reason for bankruptcy filings by such older people, with two-thirds of them providing these reasons. Evidence from the 2009 National Financial Capability Study and the TNS Debt Survey showed that people age 55+ hold widespread credit card debt and pay a great deal in fees for late payments and exceeding the credit limits - when they should be at the peak of their wealth accumulation process (Lusardi, 2011; Lusardi and Tufano, 2009a,b).

\footnotetext{
${ }^{4}$ For a few recent examples see AARP (2013), Cho (2012), Copeland (2013), Pham (2011), and Securian (2013).
} 
Moreover, these studies also detected a link between debt management and financial literacy; with those least financially literate incurring high fees and using high-cost borrowing. The least financially knowledgeable also report that their debt loads were excessive and they were often unable to judge their debt positions (Lusardi and Tufano, 2009a). This group is also more likely to borrow from their 401(k) and pension accounts (Lu et al., 2010; Utkus and Young, 2011) and use high-cost methods of borrowing such as payday loans (Lusardi, 2010).

In what follows, we contribute to the literature with two sets of empirical analyses. First, using the HRS, we compare three different cohorts of people on the verge of retirement (age 5661) at three different time periods: 1992, 2002 and 2008. Second, we examine older individuals' debt patterns using the 2009 and 2012 National Financial Capability Study (NFCS), focusing on how older households manage their debt.

\section{Evidence from the Health and Retirement Study}

The HRS is a unique dataset with both longitudinal/panel and cross-cohort features which offers insight into how debt has evolved over time among older Americans. Specifically, it reports asset and debt information for three cohorts on the verge of retirement: those interviewed in the 1992 Baseline HRS, those in the 2002 War Baby group, and the 2008 Early Baby Boomers. ${ }^{5}$ For each cohort we have comparable data on assets and debt. The difference in time periods allows us to examine how the onset of the financial crisis has affected the amount of debt that persons age 56-61 are holding as they near retirement.

\section{Cross-Sectional Results}

Table 1 describes the evolution of total debt across three cohorts. ${ }^{6}$ Total debt is measured in the HRS as the value of mortgages and other loans on the household's primary residence, other mortgages, and other debt (including credit card debt, medical debt, etc.). The percentage of people age 56-61 arriving on the verge of retirement with debt rose from $64 \%$ in 1992, to $71 \%$ by 2008. Additionally, the value of debt rose sharply over time. While the median amount of

\footnotetext{
5 The Baseline HRS cohort was born 1931 to 1941; the War Baby group was born 1942 to 1947; and the Early Baby Boomer group was born 1948 to 1953. For brevity, we sometimes refer to these three groups below as the 1992, 2002, and 2008 cohorts, respectively and we focus on those who are 56-61 years old. We also note that the survey included different numbers of respondents per cohort, since the 1992 HRS survey was substantially larger than the subsequent groups. Results reported below use unweighted data. All values are expressed in 2012 dollars.

${ }^{6}$ The analysis attributes household assets and debt to each age-eligible individual in the HRS sample. This in effect implies that all household assets and liabilities influence married and single respondents when they make economic decisions. An alternative approach might seek to allocate assets and liabilities between members of a couple, but this would not affect the debt ratios examined below.
} 
debt in 1992 was about \$6,200, median debt more than tripled by 2002 and quadrupled by 2008 (respectively $\$ 19,100$ and $\$ 28,300$, all in $\$ 2012$ ). We also see that the debt distribution appears to have changed across cohorts. The top quartile of the debt distribution held around $\$ 50,000$ in debt in 1992, while in the two later cohorts, this same quartile of the population held $\$ 100,000$ and $\$ 117,300$ respectively. Additionally, by 2008, the top 10 percent of the debt distribution reported debt of over $\$ 259,000$. Depending on the interest rate charged on this debt, these families would be very likely to feel the burden of sizeable monthly debt repayments, and to carry debt into retirement.

\section{Table 1 here}

One factor driving the increase in debt for more recent groups is that the value of primary residence mortgages is much higher for more recent cohorts. We first note, as indicated in the second panel of Table 1, that the percentage of near-retirement individuals in this age bracket having mortgage debt has risen by over 7 percentage points, from 41\% in 1992 to $48 \%$ by 2008 . Morever, and most important, mortgage debt amounts have risen as well. For instance, looking at the third quartile of the mortgage debt distribution in the whole sample (conditional on having a mortgage), we see that mortgage debt tripled from 1992 to 2008. Over the same period, the third panel shows that the percentage of respondents with loans on their primary residence grew from $10 \%$ to $16 \%$, an increase of $60 \%$, and here too, the mortgage values rose. Other mortgages (e.g., on secondary residences) also became more prevalent, though relatively few (3-5\%) held this form of debt, as is shown in the fourth panel.

The fifth panel of Table 1 indicates that other debt for older individuals on the verge of retirement also rose across cohorts, from $37 \%$ for the earliest group to $44 \%$ for the most recent cohort. The distributions also became more skewed over time. For instance, in the distribution of other debt, the $90^{\text {th }}$ decile held about $\$ 8,000$ in 1992 , while the same decile held over $\$ 21,300$ in debt by 2008. Because this category includes non-collateralized debt, which tends to charge high interest rates, our findings imply that older Americans are increasingly likely to have high monthly payments to service their debt. ${ }^{7}$ A potential concern regarding individual indebtedness trends is what will happen to debt and the financial situation of older individuals and families when short-term interest rates start to increase, in response to changes in the national policy of

\footnotetext{
${ }^{7}$ For example, it takes a monthly payment of $\$ 547$ to pay off a debt of $\$ 21,000$ charging an annual percentage rate (APR) of $20 \%$ in five years.
} 
zero or very low short-term interest rates. Similar findings are reported by Butrica and Karamcheca (2013).

Additional insight into older adults' financial situations is provided by the ratios of debt to assets shown in Table 2. Here the total assets measure includes all checking and savings accounts, CDs, money market funds, T-bills, bonds/bond funds, stocks/stock market funds, IRAs, 401(k)s/and Keoghs, the value of primary residence and other real estate, vehicles, business equity, and other savings. ${ }^{8}$ We also consider the ratio of housing debt (including home mortgages and other home loans) to the value of the house. And last, we consider the ratio of other debt to the value of liquid assets defined as the sum of checking and savings accounts, CDs, money market funds, T-bills, bonds/bond funds, and stocks/stock market funds. These ratios allow us to evaluate older adults' leverage ratios, and to assess how much of their home loans they have paid off already. This, in turn, allows us to examine whether or not people will enter retirement having to make monthly mortgage payments.

\section{Table 2 here}

Comparing Table 2 with Table 1, we see that it is not just the value of debt that has increased over time, but the proportion of debt to assets as well. Thus, older Americans are much more leveraged on the verge of retirement in the recent past, than back in 1992. For example, the first panel of Table 2 shows that the median value of total debt over total assets was rather small in 1992, i.e., only about 0.05, but this ratio increased to 0.08 in 2002 and 0.15 in 2012. ${ }^{9}$ Moreover, a sizable fraction of the 2008 cohort had ratios over 0.5 and some held debt worth as much as 0.8 times total assets.

One of the reasons for the increase in leverage is that people nearing retirement accumulated more debt on their homes over time. Fewer than half of the older individuals had a mortgage, but the ratio of that mortgage along with other home loans to the home value rose over time. The second panel of Table 2 shows that the most recent cohort nearing retirement had a much larger ratio of mortgages/home loans to pay off: at the median, the value rose from 0.06 to 0.25. This means that the most recent cohort must continue to service their mortgages and other home loans well into retirement.

\footnotetext{
${ }^{8}$ We use the measure of wealth provided in the HRS. Wealth values are winsorized at the top and bottom $0.5 \%$.

${ }^{9}$ Ratios are defined only for those who have a strictly positive value of total assets.
} 
The third panel shows that one reason why mortgage debt rose was that recent cohorts purchased more expensive homes than their predecessors. As the table shows, the value of homes owned by older individuals rose from 1992 to 2008; it remained high, even with the collapse of the housing market in 2007 cutting home values in some states by half. The trend to buying more expensive homes also meant that the percentage of total assets accounted for by the home was larger for more recent cohorts. Thus at the median of the debt ratio distribution, the 1992 cohort held about $46 \%$ of their total assets in their primary residences, but the Early Baby Boomers held $56 \%$ in their homes.

Non-mortgage debt also increased as a percentage of liquid asset values. Note that Table 2 reports these ratios conditional on the respondents having strictly positive liquid assets. A much higher proportion of families in the more recent cohorts had debt equal to or higher than liquid assets. Thus, people will need to continue to borrow or sell off other (less) liquid assets to pay off their non-collateralized debt. It is also noteworthy that a proportion of families had liquid assets even while carrying debt. Since debt is likely to incur higher interest rates than bank accounts, some families may be overlooking opportunities to better manage their balance sheets.

Next we turn to several financial fragility indicators, which reveal whether individuals on the verge of retirement have little net worth or are holding a large ratio of debt to total wealth. ${ }^{10}$ Older adults close to retirement would be anticipated to be at or near at the peak of their wealth accumulation process, and one important decision after retirement is how to decumulate wealth. As noted above, however, recent cohorts will also need to manage and pay off debt during retirement. This is made more difficult by the fact that older persons often move some of their assets to fixed income assets. In addition, if equity returns are lower over the next 20 years than in the past (as many predict), it will be important for current older cohorts to manage assets and liabilities wisely and pay off some of their higher-interest debt first. Accordingly, it appears that the more recent cohorts must ensure that their income and asset drawdowns suffice to cover not just their target consumption streams, but also to service their mortgage and other debt during retirement. We note that there may be little flexibility in adjusting mortgage payments, apart from selling the home, moving to a smaller home, or engaging in reverse mortgages, which many

\footnotetext{
10 The present analysis excludes pension and Social Security wealth. While these are important components of total wealth, in these cohorts, most still have defined benefit plans which often prohibit taking a lump sum.
} 
older cohorts in the past seemed unwilling to do, at least until late in the life cycle (Venti and Wise, 1990, 1991; Hurd, 1990).

Table 3 suggests that the prevalence of financially fragility has risen over time. While fewer than $10 \%$ of the earlier cohort neared retirement with large debt to asset ratios $(>0.5)$, by 2008 over one-fifth (22\%) of them did so, as shown in the first panel. ${ }^{11}$ Moreover, this pattern was in place prior to the financial crisis, since the ratio of debt to assets was already higher in 2002 (16\%) than in 1992. As noted earlier, part of the increase in debt can be attributed to the rise in home mortgages, and the fact that recent cohorts approached retirement with much higher ratios of mortgage debt to home values. In turn, this is because recent cohorts purchased more expensive homes than their earlier peers, which helps explain why the collapse of the housing market starting in 2007 exacerbated the ratio of mortgages and other loans compared to the value of the house. The second panel shows that almost 30\% of the 2008 cohort had loan/value ratios on their primary residences over 0.5 , whereas only $17 \%$ did in the first wave. The third panel indicates that non-mortgage debt to asset ratios also grew over time, at about the same rate. Accordingly, Boomers are likely to need to dedicate some of their liquid wealth to pay off debt in retirement, and hence this recent cohort is more exposed to the negative consequences of interest rate increases than previous cohorts.

\section{Table 3 here}

The last panel in Table 3 focuses on change in the prevalence of very low wealth, defined here as $\$ 25,000$. We focus on that cutoff as it is about half of median household income, not a very high level in the event of an old-age shock to health or some other unpleasant surprise. Results show that some $18 \%$ had very low net worth according to this definition in the 1992 cohort, whereas almost one-quarter of the 2008 cohort was in this state. For this reason, we conclude that the financial crisis both eroded savings and boosted older persons' debt share over time, likely prejudicing retirement security in the future.

\section{Multivariate Analysis}

To further examine the factors associated with financial fragility among older Americans, Table 4 summarizes results from a multivariate regression analysis on the four outcomes just discussed overall, and by marital status. That is, Panel A shows for the full sample which factors

\footnotetext{
${ }^{11}$ These values refer to only those with strictly positive assets.
} 
are associated with having (a) a total debt/asset ratio of more than 0.5, (b) a ratio of primary residence loans to home value of over 0.5; (c) other debt/liquid asset ratio over 0.5; and (d) total net worth under $\$ 25,000$. Panel B focuses only on those married/living with a partner at the time of the survey, and Panel C includes only the nonmarried subset.

\section{Table 4 here}

Several interesting findings obtain in the overall group (Panel A). First, we see that the cohort indicators are positive for all four dependent variables. Moreover, the Early Boomers group (2008 cohort) was significantly more financially fragile than the reference group (the 1992 cohort); and for three of the four outcomes the War Babies group (1998 cohort) was also significantly more fragile than the reference group. In other words, the directional conclusions from tabulations in Tables 1-3 are confirmed after including controls for potential differences in socio-demographic factors (these include age, marital status, sex, number of children ever born, race, education, income, and whether in poor health). The magnitudes of the cross-cohort differences also conform relatively well to those reported in the earlier tabulations, an unsurprising result in view of the relatively low R-squares in the multivariate analysis.

Another point worth noting is that some socio-demographic factors are significantly associated with financial fragility. For instance, being married, white, better educated, and having higher income rendered respondents much less likely to be financially fragile. Factors significantly associated with greater fragility include having had more children and being in poor health.

Panels B and C have a similar story to tell, in that both single and partnered Boomers were significantly more fragile than their counterparts in the 1992 Baseline HRS cohort. Thus, coupled respondents in the Boomer cohort were more vulnerable than prior married cohorts, while singles were also at greater risk (though slightly less so). Additionally, it is of interest to examine associations with specific correlates. For instance, poor health was a strong predictor of high debt ratios for the full sample in Panel A (in particular, non-mortgage debt ratios) and low wealth holdings close to retirement, perhaps because of medical debt. This association was quantitatively more important for singles than for couples, as can be gleaned from a comparison of Panels B and C. Similarly, singles did better when they had higher income compared to those with partners. The role of education is also worth highlighting: compared to high school 
dropouts, singles having college degrees were markedly wealthier and less likely to have high levels of debt.

\section{Evidence from the National Financial Capability Study}

Next we turn to an analysis of two waves of the NFCS, as this data source complements our analysis in the HRS in two ways: it offers more recent data and also it contains additional detail about debt and debt management unavailable in other surveys. ${ }^{12}$ The 2009 wave can readily be aligned with the 2008 wave of the HRS respondents in the same age bracket to show that the two data sources yield the same conclusions. The 2012 wave provides more recent data along with additional questions on debt and debt management post-financial crisis. ${ }^{13}$

Comparing 57-62 year old respondents in 2009 with the 2008 HRS cohort (results not detailed here) confirms that statistics are rather similar across years. For example, similar to the 2008 HRS cohort, more than half of NCFS respondents who own their home get close to retirement with mortgages. ${ }^{14}$ The NFCS data also show that down payments have been decreasing over time and that those who recently bought homes had put down only 5 or 10 percent. Even though it does not report debt values, the NFCS shows that many older respondents pay the minimum only on their credit cards and that a sizeable proportion have made use of high-cost methods of borrowing, such as payday loans, pawn shops, etc. ${ }^{15}$

Next we report information from the 2012 NCFS wave, examining respondents who are age 56-61. We do so to focus on the most recent cohort of persons on the verge of retirement as above, but now a few years after the collapse of the housing market and the financial crisis (Table 5).

\section{Table 5 here}

Once again, we see that mortgage debt and other debt proved problematic for a relatively large subset of the near-retirement respondents. Some 8\% overall reported being underwater, owing more on their homes than they thought they could sell them for (17\% of the homeowners). As far as non-mortgage debt is concerned, many respondents said they did not pay off credit card

\footnotetext{
${ }^{12}$ For more on the NFCS, see Lusardi (2011) and FINRA Investor Education Foundation (2009).

${ }^{13}$ Nevertheless, this survey did not report specific debt levels.

${ }^{14}$ According to the HRS data, 58\% percent of respondents with a home (defined as having a positive home value) had a mortgage on their primary residence in 2008. The NFCS reports a similar percentage (60.5) among respondents age 55 to 64 .

${ }^{15}$ For brevity, these statistics are not reported but are available upon request.
} 
balances in full (if they had them), and they engaged in many costly behaviors such as paying only the minimum due or using the card for cash advances. They were also charged fees for late payment or exceeding the limits. This picture reiterates the point that many older Americans are exposed to illiquidity and/or problems in debt management. Turning to other indicators, $7 \%$ of those who had retirement accounts had borrowed on them, and 6\% had taken a hardship withdrawal. Moreover, 23\% reported having unpaid medical bills, and in the five years prior to the survey, over a fifth of the age 56-61 group reported having engaged in high-cost borrowing using alternative financial services (such as rent-to-own stores, pawn shops, payday loans, auto title loans, and tax refund loans). When asked to evaluate their debt (on a scale from 1 to 7 ), about $40 \%$ indicated they had too much debt (having values of 5, 6, or 7).

A different way to evaluate household financial fragility probes how people judge their ability to deal with a financial shock. ${ }^{16}$ Specifically, the NFCS question asked respondents how confident they were that they could come up with $\$ 2,000$, if an unexpected need arose in the next month. Possible answers included certain to/probably could/probably could not/certainly could not access this amount if needed. The $\$ 2,000$ amount was selected to represent a medium-sized shock such as having a car or house repair, or an out-of-pocket medical bill. Table 5 indicates that about $36 \%$ of the age 56-61 respondents stated they probably could not/were certain they could not come up with this amount in the time indicated. Despite the fact that one might expect this age group to be at the peak of its wealth accumulation, in fact, many felt they had little or no ability to shield themselves against shocks.

\section{Multivariate Regression Analysis}

Finally, we explore the 2012 NFCS in more detail using a multivariate analysis of alternative indicators of debt and financial fragility. As mentioned above, respondents were asked if they thought they had too much debt (the indicator goes from 1 to 7 for the question 'I have too much debt right now', where 1 means strongly disagree and 7 strongly agree) and we use this variable as a proxy of problems with debt (in place of the ratios we used in the HRS). We also use an indicator equal to 1 for those who could not (probably or certainly) come up with $\$ 2,000$ in an emergency within a month. We explore these indicators using all the sociodemographics used previously to examine the HRS data. In addition, we add a control for

\footnotetext{
${ }^{16}$ This approach was piloted by Lusardi, Schneider, and Tufano (2011).
} 
whether respondents experienced a large and unexpected drop in income in the previous year. Moreover, the NFCS included a set of questions on financial literacy which provides an assessment of respondents' basic financial literacy (with 5 questions assessing numeracy, knowledge of inflation, risk diversification, and the workings of mortgages and basic asset pricing; Lusardi, 2011).

Results appear in Table 6 where Panel A reports our estimates of the factors associated with self-assessed debt, and Panel B focuses on financial fragility. Two specifications appear in each panel, where the first one controls on socio-demographics and income shocks, while the second also incorporates a financial literacy index (defined as the number of correct answers to the five financial literacy questions). In both columns, results show that older and higher income persons were systematically less likely to report being in debt, whereas having had more children was strongly associated with reporting excessive debt. Those who experienced a large and unexpected drop in income during the previous year also agreed they were over-indebted, suggesting that shocks do play a role in the accumulation of debt close to retirement. Results in the second column are similar, with the additional finding that the more financially literate were less likely to report they had excessive debt. In other words, shocks do play a role in the accumulation of debt close to retirement. But it is not enough to have resources, people also need the capacity to manage those resources if they are to stay out of debt as they head into retirement.

\section{Table 6 here}

Next we explore the factors associated with whether people said they could come up with $\$ 2,000$ in 30 days, with estimates reported in Panel B. As in the HRS results on the chances of holding low wealth (less than $\$ 25,000$ which is roughly the monthly value of $\$ 2,000$ multiplied by 12), here we see that being male and/or White, having higher income, and being better educated, are all important factors. Financial literacy also plays a role: being able to answer one additional financial literacy question correctly was associated with a lower probability (by 3 percentage points) of being financially fragile. Also having more children and having had an income shock made these respondents more likely to report they were financially fragile. According to our estimates, those who experienced such shocks were 12 percentage points more likely to be financially fragile. 


\section{Implications and Policy Relevance}

Prior to the recent financial crisis and Great Recession, consumer credit and mortgage borrowing expanded rapidly, leaving relatively unsophisticated consumers in the historically unusual position of being able to decide how much they could afford to borrow. Whether and how cohorts on the verge of retirement appear to have changed their debt levels and financial fragility is important for understanding near-term consequences, for instance, as a factor spurring bankruptcy, and in the long run, determining lifetime wealth sufficiency and retirement security.

Our paper analyzed older individuals’ debt and debt management practices using data from the Health and Retirement Study (HRS) and the National Financial Capability Study (NFCS). Specifically, we examine three different cohorts of persons age 56-61 surveyed by the HRS, at three different time points, namely 1992, 2002 and 2008. Our analysis provides an evaluation of cross-cohort changes in debt over time. We also offer detail on financial fragility using the recent National Financial Capability Study (NFCS), showing how older persons manage their debt on the verge of retirement. Our goal was to assess how wealth and debt among older persons has evolved over time, along with the potential consequences for retirement security. Results indicate that more recent cohorts have, indeed, taken on more debt and face more financial insecurity, mostly due to having purchased more expensive homes with smaller down payments. In addition, Baby Boomers are more likely to have engaged in the use of costly alternative financial services. Factors reducing exposure to debt include having higher income, more education, and greater financial literacy. Factors associated with greater financial fragility include having had more children, poor health, and unexpected large income declines.

It is interesting that most theoretical models of household portfolios have tended to focus on household portfolio patterns without devoting much attention to debt patterns (e.g., Lusardi, Michaud, and Mitchell, 2011; Delavande, Rohwedder, and Willis, 2008; Chai et al. 2012). The present research indicates that analysts and policymakers in the future may be interested in

formulations that incorporate debt and debt management practices into the factors driving retirement security. The fact that there is often a wedge between interest rates charged on debt versus returns that people can earn on their saving is generally not taken into account. Moreover, extant models tend to overlook the fact that interest rates charged to individuals are not fixed but can be shaped by peoples' behavior. Our paper thus motivates additional research on key aspects of debt and debt management for future policy analysis. 


\section{References}

AARP. 2013. In the Red: Older Americans and Credit Card Debt. AARP Public Policy Institute Report. www.aarp.org

Agarwal, S., J. Driscoll, X. Gabaix, and D. Laibson. 2009. “The Age of Reason: Financial Decisions over the Lifecycle with Implications for Regulation.” Brookings Papers on Economic Activity: 51-101.

Bucks, B., A. Kennickell, T. Mach, and K. Moore. 2009. "Changes in U.S. Family Finances from 2004 to 2007: Evidence from the Survey of Consumer Finances.” Federal Reserve Bulletin 95: A1-A55.

Butrica, B. and N. Karamcheva. 2013. Does Household Debt Influence the Labor Supply and Benefit Claiming Decisions of Older Americans? Working Paper, Urban Institute.

Chai, J., W. Horneff, R. Maurer, and O. S. Mitchell. 2011. "Optimal Portfolio Choice over the Life Cycle with Flexible Work, Endogenous Retirement, and Lifetime Payouts.” Review of Finance. 15(4): 875-907.

Cho, H. 2012. "Seniors Grow Old Under Debt.” The Baltimore Sun/New America Media. http://newamericamedia.org/2012/05/seniors-grow-old-under-debt.php

Copeland, C. 2013. “Debt of the Elderly and Near Elderly, 1992-2010.” EBRI Notes. February $34(2)$.

Delavande, A., S. Rohwedder, and R. Willis. 2008. "Preparation for Retirement, Financial Literacy and Cognitive Resources.” MRRC Working Paper 2008-190.

Financial Industry Regulatory Authority (FINRA). 2006. Investor Literacy and Fraud Susceptibility Survey Executive Summary. Retrieved 2-29-2012. http://www.finra.org/Investors/ProtectYourself/AvoidInvestmentFraud/.

Financial Industry Regulatory Authority (FINRA). 2007. Senior Fraud Risk Survey. Retrieved 22-2012. http://www.finra.org/Investors/ProtectYourself/AvoidInvestmentFraud/.

Hurd, M. 1990. "Research on the Elderly: Economic Status, Retirement, Consumption, and Saving,” Journal of Economic Literature 28: 565-637.

Lu, T., O. S. Mitchell, and S. P. Utkus. 2010. “An Empirical Analysis of 401(k) Loan Defaults.” Financial Literacy Consortium Report to the SSA. September.

Lusardi, A. 2010. "Financial Capability in the United States: Consumer Decision-Making and the Role of Social Security.” MRRC Working Paper 2010-226.

Lusardi, A. 2011. “Americans’ Financial Capability.” NBER Working Paper 17103.

Lusardi, A, and C. de Bassa Scheresberg. 2013. "Financial Literacy and High-Cost Borrowing in the United States.” NBER Working Paper 18969.

Lusardi, A., and O. S. Mitchell. 2007. "Baby Boomer Retirement Security: The Role of Planning, Financial Literacy and Housing Wealth.” Journal of Monetary Economics 54: 205-224.

Lusardi, A., and O. S. Mitchell. 2008. "Planning and Financial Literacy: How Do Women Fare?” American Economic Review 98: 413-417. 
Lusardi, A., and O. S. Mitchell. 2011a. “The Outlook for Financial Literacy.” In O. S. Mitchell and A. Lusardi, eds., Financial Literacy: Implications for Retirement Security and the Financial Marketplace. Oxford, UK: Oxford University Press: 1-13.

Lusardi, A., and O. S. Mitchell. 2011b. "Financial Literacy and Planning: Implications for Retirement Wellbeing.” In O. S. Mitchell and A. Lusardi, eds., Financial Literacy: Implications for Retirement Security and the Financial Marketplace. Oxford, UK: Oxford University Press: 17-39

Lusardi, A., and O. S. Mitchell. 2011c . "Financial Literacy and Retirement Planning in the United States.” Journal of Pension Economics and Finance 10: 509-525.

Lusardi, A and O.S. Mitchell. 2014. The Economic Importance of Financial Literacy: Theory and Evidence.” Forthcoming, Journal of Economic Literature, March (NBER WP 18952).

Lusardi, A., O. S. Mitchell, and V. Curto. 2010. “Financial Literacy among the Young.” Journal of Consumer Affairs 44(2): 358-380.

Lusardi, A., O. S. Mitchell, and V. Curto. 2012. "Financial Sophistication among the Older Population.” NBER Working Paper 15469.

Lusardi, A., P-C. Michaud, and O. S. Mitchell.2013. "Optimal Financial Knowledge and Wealth Inequality.” NBER WP 18669.

Lusardi, A, D. Schneider, and P. Tufano. 2011. "Financially Fragile Households: Evidence and Implications.” Brookings Papers on Economic Activity Spring: 83-134.

Lusardi, A., and P. Tufano. 2009a. "Debt Literacy, Financial Experiences, and Overindebtedness.” NBER WP 14808.

Lusardi, A., and P. Tufano. 2009b. “Teach Workers about the Peril of Debt.” Harvard Business Review. 22(4).

Mottola, G.R. 2013. "In Our Best Interest: Women, Financial Literacy and Credit Card Behavior.” Numeracy, vol. 6 (2), Article 4.

Pham, S. 2011. "Retirements Swallowed by Debt.” New York Times. January 26. newoldage.blogs.nytimes.com/2011/01/26/retirements-swallowed-by-debt/

Pottow, J. 2012. “The Rise in Elder Bankruptcy Filings and Failure of U.S. Bankruptcy Law.” The Elder Law Journal 19: 220-257.

Securian Financial Group. 2013. Retirement Time Bomb: Mortgage Debt. Securian Investments. www.securiannews.com/sites/securian.newshq.businesswire.com/files/research/file/RetDebtSummaryApr2013-F78685-1_pod.pdf

Venti, S., and D. Wise. 1990. "But They Don't Want to Reduce Housing Equity.” In Issues in the Economics of Aging, University of Chicago Press.

Venti, S., and D. Wise. 1991. “Aging and the Income Value of Housing Wealth,” Journal of Public Economics 44.

Utkus, S., and J. Young. 2011. “Financial Literacy and 401(k) Loans.” In O.S. Mitchell and A. Lusardi, eds., Financial Literacy: Implications for Retirement Security and the Financial Marketplace. Oxford, UK: Oxford University Press: 59-75. 
Table 1. Levels and Distribution of Cohort Total Debt and Debt Components in the Health and Retirement Study (HRS)

\begin{tabular}{|c|c|c|c|c|c|c|c|c|}
\hline & $\begin{array}{c}\text { \% debt } \\
\text { owners in } \\
\text { total sample } \\
\end{array}$ & p10 & p25 & p50 & p75 & p90 & Mean & $\mathbf{N}$ \\
\hline \multicolumn{9}{|l|}{ 1. Total debt } \\
\hline HRS & $63.79 \%$ & 0 & 0 & 6,218 & 49,091 & 106,363 & 37,514 & 4,675 \\
\hline War Babies & $67.57 \%$ & 0 & 0 & 19,147 & 99,565 & 191,470 & 66,228 & 1,178 \\
\hline Early Baby Boomers & $71.42 \%$ & 0 & 0 & 28,259 & 117,301 & 259,130 & 87,835 & 1,627 \\
\hline \multicolumn{9}{|c|}{$\begin{array}{l}\text { 2. Value of all } \\
\text { mortgages/land } \\
\text { contracts (1ry residence) }\end{array}$} \\
\hline HRS & $40.47 \%$ & 0 & 0 & 0 & 31,091 & 81,818 & 26,196 & 4,675 \\
\hline War Babies & $47.20 \%$ & 0 & 0 & 0 & 74,035 & 165,941 & 52,766 & 1,178 \\
\hline Early Baby Boomers & $47.82 \%$ & 0 & 0 & 0 & 94,908 & 207,944 & 66,326 & 1,627 \\
\hline \multicolumn{9}{|c|}{$\begin{array}{l}\text { 3. Value of other home } \\
\text { loans (1ry residence) }\end{array}$} \\
\hline HRS & $9.97 \%$ & 0 & 0 & 0 & 0 & 0 & 4,365 & 4,675 \\
\hline War Babies & $11.97 \%$ & 0 & 0 & 0 & 0 & 10,212 & 4,674 & 1,178 \\
\hline Early Baby Boomers & $15.98 \%$ & 0 & 0 & 0 & 0 & 19,195 & 7,924 & 1,627 \\
\hline \multicolumn{9}{|l|}{$\begin{array}{l}\text { 4alue of all } \\
\text { mortgages/land } \\
\text { contracts (2ndry } \\
\text { residence) }\end{array}$} \\
\hline HRS & $5.73 \%$ & 0 & 0 & 0 & 0 & 0 & 3,318 & 4,675 \\
\hline War Babies & $3.23 \%$ & 0 & 0 & 0 & 0 & 0 & 3,430 & 1,178 \\
\hline Early Baby Boomers & $4.00 \%$ & 0 & 0 & 0 & 0 & 0 & 5,220 & 1,627 \\
\hline \multicolumn{9}{|c|}{ 5. Value of other debt } \\
\hline HRS & $36.94 \%$ & 0 & 0 & 0 & 2,291 & 8,182 & 3,634 & 4,675 \\
\hline War Babies & $37.01 \%$ & 0 & 0 & 0 & 3,829 & 15,318 & 5,358 & 1,178 \\
\hline Early Baby Boomers & $44.44 \%$ & 0 & 0 & 0 & 5,332 & 21,328 & 8,364 & 1,627 \\
\hline
\end{tabular}

Note: The sample includes all age-eligible individuals age 56-61 in the cohort indicated. HRS cohort observed in 1992; War Babies observed in 2002; Early Baby Boomers observed in 2010. Total debt includes the value of mortgages and other loans on the household's primary residence, other mortgages, and other debt (including credit card debt, medical debt, etc.). All dollar values in \$2012. Percentiles indicated in percentiles. Data unweighted. 
Table 2. Levels and Distribution of Cohort Total Debt Ratios and Debt Ratio Components in the HRS

\begin{tabular}{|c|c|c|c|c|c|c|c|}
\hline & p10 & p25 & p50 & p75 & p90 & Mean & $\mathbf{N}$ \\
\hline $\begin{array}{ll}\text { 1. } & \text { Total debt/Total } \\
\text { assets }\end{array}$ & & & & & & & \\
\hline HRS & 0 & 0 & 0.05 & 0 & 0 & 1 & 4,437 \\
\hline War Babies & 0 & 0 & 0.08 & 0 & 1 & 1 & 1,147 \\
\hline Early Baby Boomers & 0 & 0 & 0.15 & 0 & 1 & 4 & 1,557 \\
\hline $\begin{array}{l}\text { 2. All 1ry res. } \\
\text { loans/1ry res. valu }\end{array}$ & & & & & & & \\
\hline HRS & 0 & 0 & 0.06 & 0.37 & 1 & 0 & 3,771 \\
\hline War Babies & 0 & 0 & 0.17 & 0.53 & 1 & 3 & 983 \\
\hline Early Baby Boomers & 0 & 0 & 0.25 & 0.58 & 1 & 0 & 1,268 \\
\hline $\begin{array}{l}\text { 3. Value of 1ry } \\
\text { residence/Total } \\
\text { assets }\end{array}$ & & & & & & & \\
\hline HRS & 0 & 0.19 & 0.46 & 0.75 & 0.92 & 0 & 4,437 \\
\hline War Babies & 0 & 0.24 & 0.51 & 0.78 & 0.93 & 1 & 1,147 \\
\hline Early Baby Boomers & 0 & 0.23 & 0.56 & 0.84 & 0.94 & 1 & 1,557 \\
\hline $\begin{array}{l}\text { 4. Value of 1ry } \\
\text { residence }\end{array}$ & & & & & & & \\
\hline HRS & 49,091 & 81,818 & 130,909 & 212,726 & 327,271 & 167,468 & 3,771 \\
\hline War Babies & 57,441 & 102,117 & 178,706 & 306,352 & 478,676 & 244,324 & 983 \\
\hline Early Baby Boomers & 63,983 & 117,301 & 213,275 & 351,904 & 533,189 & 292,630 & 1,268 \\
\hline $\begin{array}{l}\text { 5. Other debt/Liquid } \\
\text { assets }\end{array}$ & & & & & & & \\
\hline HRS & 0 & 0 & 0 & 0.16 & 2 & 6 & 3,853 \\
\hline War Babies & 0 & 0 & 0 & 0.22 & 4 & 14 & 1,047 \\
\hline Early Baby Boomers & 0 & 0 & 0 & 1 & 10 & 46 & 1,341 \\
\hline
\end{tabular}

Note: Total assets include all checking and savings accounts, CDs, money market funds, T-bills, bonds/bond funds, stocks/stock market funds, IRAs, 401(k)s/and Keoghs, the value of primary residence and other real estate, vehicles, business equity, and other savings. Housing debt includes home mortgages and other home loans. Liquid assets are defined as the sum of checking and savings accounts, CDs, money market funds, T-bills, bonds/ bond funds, and stocks/stock market funds See also Table 1. 
Table 3. Levels of Cohort Total Debt/Asset Ratios, and Debt Component/Asset Ratios in the HRS

$\% \quad \mathbf{N}$

1. Total debt/Total assets $>0.5$

HRS

$9.56 \% \quad 4,437$

War Babies

$15.95 \% \quad 1,147$

Early Baby Boomers

$22.86 \% \quad 1,557$

2. All 1ry Res Loans/1ry Res. Value $>0.5$ HRS

$17.02 \% \quad 3,771$

War Babies

26.35\% 983

Early Baby Boomers

$29.34 \% \quad 1,268$

3. Other debt/Liquid assets $>0.5$

HRS

$17.54 \% \quad 3,853$

War Babies

Early Baby Boomers

$21.39 \% \quad 1,047$

$28.78 \% \quad 1,341$

4. Respondents with less than $\$ 25,000$ in savings HRS

$18.03 \% \quad 4,675$

War Babies

$16.38 \% \quad 1,178$

Early Baby Boomers

$24.28 \% \quad 1,627$

Note: See Tables 1 and 2. 
Table 4. Multivariate Analysis of the Factors Associated with Financial Fragility in the HRS

\section{A. Full Sample}

\begin{tabular}{|c|c|c|c|c|}
\hline & $\begin{array}{l}\text { Total } \\
\text { debt/Total }\end{array}$ & $\begin{array}{l}\text { 1ry residence } \\
\text { ratio }>0.50\end{array}$ & $\begin{array}{l}\text { Other debt/Liquid } \\
\text { assets }>0.50\end{array}$ & $\begin{array}{l}\text { Total net wealth } \\
<\$ 25,000\end{array}$ \\
\hline \multirow[t]{2}{*}{ War babies } & $0.068 * * *$ & $0.074 * * *$ & $0.053 * * *$ & 0.013 \\
\hline & $(0.013)$ & $(0.018)$ & $(0.016)$ & $(0.012)$ \\
\hline \multirow[t]{2}{*}{ Early boomers } & $0.132 * * *$ & $0.101 * * *$ & $0.127 * * *$ & $0.071 * * *$ \\
\hline & $(0.014)$ & $(0.017)$ & $(0.017)$ & $(0.012)$ \\
\hline \multirow[t]{2}{*}{ Married } & $-0.04 * * *$ & $-0.038 * *$ & $-0.04 * * *$ & $-0.214 * * *$ \\
\hline & $(0.011)$ & $(0.015)$ & $(0.014)$ & $(0.012)$ \\
\hline \multirow[t]{2}{*}{ Male } & 0.011 & $0.034 * * *$ & 0.01 & 0.006 \\
\hline & $(0.007)$ & $(0.009)$ & $(0.008)$ & $(0.007)$ \\
\hline \multirow[t]{2}{*}{ Childnum } & $0.004 *$ & $0.014 * * *$ & $0.016 * * *$ & $0.011 * * *$ \\
\hline & $(0.002)$ & $(0.003)$ & $(0.003)$ & $(0.002)$ \\
\hline \multirow[t]{2}{*}{ White } & $-0.041 * * *$ & $-0.032 * *$ & $-0.082 * * *$ & $-0.13 * * *$ \\
\hline & $(0.012)$ & $(0.016)$ & $(0.017)$ & $(0.013)$ \\
\hline \multirow[t]{2}{*}{ Education_hs } & $-0.02 *$ & 0.012 & -0.012 & $-0.126 * * *$ \\
\hline & $(0.011)$ & $(0.014)$ & $(0.014)$ & $(0.012)$ \\
\hline \multirow[t]{2}{*}{ Education_smcl } & -0.021 & 0.022 & $-0.038 * *$ & $-0.158 * * *$ \\
\hline & $(0.015)$ & $(0.018)$ & $(0.018)$ & $(0.014)$ \\
\hline \multirow[t]{2}{*}{ Education_gtcl } & $-0.036 * *$ & 0.035 & $-0.056 * * *$ & $-0.158 * * *$ \\
\hline & $(0.017)$ & $(0.023)$ & $(0.020)$ & $(0.015)$ \\
\hline \multirow[t]{2}{*}{ Hitot } & $-0.001 * *$ & $0.004 * * *$ & $-0.003 * * *$ & $-0.004 * * *$ \\
\hline & $(0.001)$ & $(0.001)$ & $(0.001)$ & $(0.001)$ \\
\hline \multirow[t]{2}{*}{ Poorhealth } & $0.051 * * *$ & -0.005 & $0.083 * * *$ & $0.153 * * *$ \\
\hline & $(0.011)$ & $(0.014)$ & $(0.015)$ & $(0.012)$ \\
\hline \multirow[t]{2}{*}{ Constant } & $0.43 * * *$ & $0.793 * * *$ & $0.592 * * *$ & $1.025 * * *$ \\
\hline & $(0.146)$ & $(0.200)$ & (0.187) & $(0.147)$ \\
\hline $\mathrm{N}$ & 7,141 & 6,022 & 6,241 & 7,480 \\
\hline $\mathrm{R} 2$ & 0.045 & 0.034 & 0.053 & 0.254 \\
\hline
\end{tabular}

Notes: Coefficient estimates from OLS regression, standard errors in parentheses. Data unweighted. See Table 3 for dependent variable definitions. Explanatory variables include age, married indicator, male, number of children, white, educational attainment indicators (high school, some college, college degree with reference category high school dropout), total household income, and indicator of poor health. See also Tables 1-3.

$* * * \mathrm{p}<0.01,{ }^{* *} \mathrm{p}<0.05,{ }^{*} \mathrm{p}<0.1$

(continued) 
(continued)

B. Married Only Sample

\begin{tabular}{|c|c|c|c|c|}
\hline & $\begin{array}{c}\text { Total debt/Total } \\
\text { assets }>0.50\end{array}$ & $\begin{array}{c}\text { 1ry Residence } \\
\text { Ratio > } 0.50\end{array}$ & $\begin{array}{l}\text { Other debt/Liquid } \\
\text { assets }>0.50\end{array}$ & $\begin{array}{l}\text { Total net wealth }< \\
\qquad \$ 25,000\end{array}$ \\
\hline War babies & $\begin{array}{l}0.074 * * * \\
(0.016)\end{array}$ & $\begin{array}{l}0.086 * * * \\
(0.021)\end{array}$ & $\begin{array}{l}0.041 * * \\
(0.019)\end{array}$ & $\begin{array}{l}0.024 * \\
(0.012)\end{array}$ \\
\hline Early boomers & $\begin{array}{l}0.142 * * * \\
(0.017)\end{array}$ & $\begin{array}{l}0.12 * * * \\
(0.021)\end{array}$ & $\begin{array}{l}0.117 * * * \\
(0.020)\end{array}$ & $\begin{array}{l}0.076 * * * \\
(0.014)\end{array}$ \\
\hline Male & $\begin{array}{l}0.029 * * * \\
(0.007)\end{array}$ & $\begin{array}{l}0.051 * * * \\
(0.009)\end{array}$ & $\begin{array}{l}0.025 * * * \\
(0.009)\end{array}$ & $\begin{array}{r}0.006 \\
(0.007)\end{array}$ \\
\hline Childnum & $\begin{array}{l}0.006 * * \\
(0.003)\end{array}$ & $\begin{array}{l}0.016 * * * \\
(0.004)\end{array}$ & $\begin{array}{l}0.019 * * * \\
(0.004)\end{array}$ & $\begin{array}{l}0.013 * * * \\
(0.003)\end{array}$ \\
\hline White & $\begin{array}{l}-0.042 * * * \\
(0.016)\end{array}$ & $\begin{array}{l}-0.037 * \\
(0.019)\end{array}$ & $\begin{array}{l}-0.099 * * * \\
(0.022)\end{array}$ & $\begin{array}{l}-0.128 * * * \\
(0.016)\end{array}$ \\
\hline Education_hs & $\begin{array}{l}-0.029 * * \\
(0.013)\end{array}$ & $\begin{array}{r}0.015 \\
(0.015)\end{array}$ & $\begin{array}{l}-0.014 \\
(0.016)\end{array}$ & $\begin{array}{l}-0.097 * * * \\
(0.013)\end{array}$ \\
\hline Education_smcl & $\begin{array}{l}-0.028 * \\
(0.017)\end{array}$ & $\begin{array}{r}0.018 \\
(0.021)\end{array}$ & $\begin{array}{l}-0.022 \\
(0.020)\end{array}$ & $\begin{array}{l}-0.108 * * * \\
(0.014)\end{array}$ \\
\hline Education_gtcl & $\begin{array}{l}-0.056 * * * \\
(0.019)\end{array}$ & $\begin{array}{r}-0.001 \\
(0.025)\end{array}$ & $\begin{array}{l}-0.048 * * \\
(0.022)\end{array}$ & $\begin{array}{l}-0.098 * * * \\
(0.015)\end{array}$ \\
\hline Hitot & $\begin{array}{l}-0.001 * * \\
(0.001)\end{array}$ & $\begin{array}{l}0.004 * * * \\
(0.001)\end{array}$ & $\begin{array}{l}-0.003 * * * \\
(0.001)\end{array}$ & $\begin{array}{l}-0.004 * * * \\
0.000\end{array}$ \\
\hline Poorhealth & $\begin{array}{l}0.041 * * * \\
(0.013)\end{array}$ & $\begin{array}{r}-0.01 \\
(0.016) \\
\end{array}$ & $\begin{array}{l}0.085 * * * \\
(0.018)\end{array}$ & $\begin{array}{l}0.114 * * * \\
(0.014)\end{array}$ \\
\hline Constant & $\begin{array}{l}0.524 * * * \\
(0.157)\end{array}$ & $\begin{array}{r}0.728 * * * \\
(0.219)\end{array}$ & $\begin{array}{l}0.756 * * * \\
(0.207)\end{array}$ & $\begin{array}{l}0.707 * * * \\
(0.145)\end{array}$ \\
\hline $\mathrm{N}$ & 5,321 & 4,819 & 4,779 & 5,386 \\
\hline $\mathrm{R} 2$ & 0.049 & 0.042 & 0.052 & 0.146 \\
\hline
\end{tabular}

Notes: Coefficient estimates from OLS regression, standard errors in parentheses. Data unweighted. See Table 3 for dependent variable definitions. Explanatory variables include age, married indicator, male, number of children, white, educational attainment indicators (high school, some college, college degree with reference category high school dropout), total household income, and indicator of poor health. See also Tables 1-3.

*** $\mathrm{p}<0.01,{ }^{* *} \mathrm{p}<0.05,{ }^{*} \mathrm{p}<0.1$

(continued) 
(continued)

C. Single Only Sample

\begin{tabular}{|c|c|c|c|c|}
\hline & $\begin{array}{l}\text { Total debt/Total } \\
\text { assets }>0.50\end{array}$ & $\begin{array}{l}\text { 1ry Residence } \\
\text { ratio }>0.50\end{array}$ & $\begin{array}{l}\text { Other debt/Liquid } \\
\text { assets }>0.50\end{array}$ & $\begin{array}{l}\text { Total net wealth }< \\
\$ 25,000\end{array}$ \\
\hline War babies & $\begin{array}{l}0.051 * * \\
(0.025)\end{array}$ & $\begin{array}{r}0.034 \\
(0.034)\end{array}$ & $\begin{array}{l}0.082 * * * \\
(0.031)\end{array}$ & $\begin{array}{l}-0.024 \\
(0.026)\end{array}$ \\
\hline Early boomers & $\begin{array}{l}0.104 * * * \\
(0.024)\end{array}$ & $\begin{array}{r}0.035 \\
(0.031) \\
\end{array}$ & $\begin{array}{l}0.155 * * * \\
(0.029)\end{array}$ & $\begin{array}{l}0.058 * * \\
(0.024)\end{array}$ \\
\hline Age & $\begin{array}{r}0.002 \\
(0.006)\end{array}$ & $\begin{array}{l}-0.015 * \\
(0.008)\end{array}$ & $\begin{array}{r}0.006 \\
(0.007)\end{array}$ & $\begin{array}{l}-0.012 * \\
(0.006)\end{array}$ \\
\hline Male & $\begin{array}{l}-0.05 * * * \\
(0.019)\end{array}$ & $\begin{array}{l}-0.045 * \\
(0.026)\end{array}$ & $\begin{array}{l}-0.052 * * \\
(0.024)\end{array}$ & $\begin{array}{r}0.014 \\
(0.021)\end{array}$ \\
\hline Childnum & $\begin{array}{r}-0.003 \\
(0.004)\end{array}$ & $\begin{array}{r}0.007 \\
(0.006)\end{array}$ & $\begin{array}{r}0.005 \\
(0.006)\end{array}$ & $\begin{array}{r}0 \\
(0.005)\end{array}$ \\
\hline White & $\begin{array}{l}-0.035 * \\
(0.021)\end{array}$ & $\begin{array}{r}-0.016 \\
(0.027)\end{array}$ & $\begin{array}{l}-0.046 * \\
(0.027)\end{array}$ & $\begin{array}{l}-0.116 * * * \\
(0.021)\end{array}$ \\
\hline Education_hs & $\begin{array}{r}0.007 \\
(0.023)\end{array}$ & $\begin{array}{r}-0.002 \\
(0.030)\end{array}$ & $\begin{array}{r}-0.002 \\
(0.031)\end{array}$ & $\begin{array}{l}-0.183 * * * \\
(0.025)\end{array}$ \\
\hline Education_smcl & $\begin{array}{r}-0.005 \\
(0.031)\end{array}$ & $\begin{array}{r}0.028 \\
(0.042)\end{array}$ & $\begin{array}{l}-0.088 * * \\
(0.037)\end{array}$ & $\begin{array}{l}-0.276 * * * \\
(0.033)\end{array}$ \\
\hline Education_gtcl & $\begin{array}{r}0.011 \\
(0.037)\end{array}$ & $\begin{array}{l}0.151 * * * \\
(0.052)\end{array}$ & $\begin{array}{l}-0.085 * * \\
(0.043)\end{array}$ & $\begin{array}{l}-0.295 * * * \\
(0.039)\end{array}$ \\
\hline Hitot & $\begin{array}{r}-0.002 \\
(0.001)\end{array}$ & $\begin{array}{l}0.005 * * \\
(0.003)\end{array}$ & $\begin{array}{l}-0.004 * * * \\
(0.001)\end{array}$ & $\begin{array}{l}-0.017 * * * \\
(0.004)\end{array}$ \\
\hline Poorhealth & $\begin{array}{l}0.075 * * * \\
(0.022)\end{array}$ & $\begin{array}{r}0.015 \\
(0.028) \\
\end{array}$ & $\begin{array}{l}0.077 * * * \\
(0.029)\end{array}$ & $\begin{array}{l}0.203 * * * \\
(0.023)\end{array}$ \\
\hline Constant & $\begin{array}{r}0.068 \\
(0.351) \\
\end{array}$ & $\begin{array}{l}1.05 * * \\
(0.480) \\
\end{array}$ & $\begin{array}{r}-0.072 \\
(0.430) \\
\end{array}$ & $\begin{array}{l}1.29 * * * \\
(0.368)\end{array}$ \\
\hline $\begin{array}{l}\mathrm{N} \\
\mathrm{R} \text { ? }\end{array}$ & $\begin{array}{r}1,820 \\
0,33\end{array}$ & $\begin{array}{l}1,203 \\
0029\end{array}$ & 1,462 & $\begin{array}{l}2,094 \\
272\end{array}$ \\
\hline
\end{tabular}

Notes: Coefficient estimates from OLS regression, standard errors in parentheses. Data unweighted. See Table 3 for dependent variable definitions. Explanatory variables include age, married indicator, male, number of children, white, educational attainment indicators (high school, some college, college degree with reference category high school dropout), total household income, and indicator of poor health. See also Tables 1-3.

*** $\mathrm{p}<0.01$, ** $\mathrm{p}<0.05$, * $\mathrm{p}<0.1$ 
Table 5. Level and Composition of Self-Reported Household Debt and Debt Concerns: 2012 National Financial Capability Study (NFCS)

\begin{tabular}{lrr}
\hline Self-Reported Debt and Debt Concerns & Age 56-61 & All \\
sample \\
\hline Underwater with home value* & $17.0 \%$ & $22.4 \%$ \\
Credit card fees, at least one type* & $31.4 \%$ & $36.8 \%$ \\
Loan on retirement accounts* & $7.0 \%$ & $11.8 \%$ \\
Hardship withdrawal from retirement accounts* & $5.7 \%$ & $8.7 \%$ \\
Unpaid medical bills & $23.4 \%$ & $25.8 \%$ \\
High-cost borrowing & $21.2 \%$ & $29.5 \%$ \\
Too much debt & $39.9 \%$ & $41.8 \%$ \\
Cannot come up with \$2,000 & $35.5 \%$ & $39.1 \%$ \\
N & 2,983 & 25,509 \\
\hline Note: The sample includes all age-eligible individuals age & $56-61$ in \\
the 2012 NCFS. Statistics related to hardship withdrawal and loan \\
and retirement account are conditional to owning a retirement \\
account. Statistics weighted using sample weights. \\
* Values conditional on holding the asset or debt.
\end{tabular}


Table 6. Determinants of Self-assessed Debt Status in the 2012 NFCS

Panel A. Multivariate Regression Model of Self-assessed Debt

\begin{tabular}{|c|c|c|}
\hline & (1) & (2) \\
\hline \multirow[t]{2}{*}{ Age } & $-0.080 * * *$ & $-0.079 * * *$ \\
\hline & $(0.026)$ & $(0.026)$ \\
\hline \multirow[t]{2}{*}{ Married } & -0.040 & -0.039 \\
\hline & $(0.110)$ & (0.110) \\
\hline \multirow[t]{2}{*}{ White } & -0.156 & -0.127 \\
\hline & (0.113) & (0.114) \\
\hline \multirow[t]{2}{*}{ Male } & 0.064 & 0.115 \\
\hline & $(0.093)$ & $(0.095)$ \\
\hline \multirow[t]{2}{*}{ Number of dependent Children } & $0.236 * * *$ & $0.233^{* * *}$ \\
\hline & $(0.056)$ & $(0.056)$ \\
\hline \multirow[t]{2}{*}{ Ed. High School } & -0.120 & -0.071 \\
\hline & $(0.221)$ & $(0.221)$ \\
\hline \multirow{2}{*}{ Ed. Some College } & -0.117 & -0.036 \\
\hline & $(0.222)$ & $(0.223)$ \\
\hline \multirow[t]{2}{*}{ Ed. College or More } & -0.237 & -0.128 \\
\hline & (0.229) & $(0.233)$ \\
\hline \multirow[t]{2}{*}{ Income \$15k-\$25k } & 0.111 & 0.122 \\
\hline & $(0.205)$ & $(0.205)$ \\
\hline \multirow[t]{2}{*}{ Income $\$ 25 \mathrm{k}-\$ 35 \mathrm{k}$} & -0.212 & -0.190 \\
\hline & $(0.210)$ & $(0.211)$ \\
\hline \multirow[t]{2}{*}{ Income $\$ 35 \mathrm{k}-\$ 50 \mathrm{k}$} & -0.231 & -0.200 \\
\hline & $(0.201)$ & $(0.202)$ \\
\hline \multirow[t]{2}{*}{ Income $\$ 50 \mathrm{k}-\$ 75 \mathrm{k}$} & $-0.418 * *$ & $-0.365 *$ \\
\hline & $(0.193)$ & $(0.195)$ \\
\hline \multirow[t]{2}{*}{ Income $\$ 75 \mathrm{k}-\$ 100 \mathrm{k}$} & $-0.760 * * *$ & $-0.691 * * *$ \\
\hline & $(0.221)$ & $(0.224)$ \\
\hline \multirow[t]{2}{*}{ Income \$100k-\$150k } & $-0.820 * * *$ & $-0.751 * * *$ \\
\hline & $(0.224)$ & $(0.227)$ \\
\hline \multirow[t]{2}{*}{ Income $>\$ 150 \mathrm{k}$} & $-1.359 * * *$ & $-1.280^{* * *}$ \\
\hline & $(0.232)$ & $(0.236)$ \\
\hline \multirow[t]{2}{*}{ Income Shock } & $0.750 * * *$ & $0.750 * * *$ \\
\hline & (0.107) & $(0.107)$ \\
\hline \multirow[t]{2}{*}{ FinLit Index } & & $-0.080 * *$ \\
\hline & & (0.038) \\
\hline \multirow[t]{2}{*}{ Constant } & $8.986 * * *$ & $9.006^{* * *}$ \\
\hline & (1.572) & (1.571) \\
\hline Observations & 2940 & 2940 \\
\hline R-squared & 0.085 & 0.086 \\
\hline
\end{tabular}

Note: The sample includes all age-eligible individuals age 56-61 in the 2012 NCFS; estimates weighted using sample weights. The dependent variable is the response to the following question: "How strongly do you agree or disagree with the following statement? 'I have too much debt right now.' Values range from 1 to 7, where 1 means 'I strongly disagree' and 7 'I strongly agree.' Robust standard errors in parentheses

*** $\mathrm{p}<0.01$, ** $\mathrm{p}<0.05, * \mathrm{p}<0.1$ 


\section{Panel B. Multivariate Regression Model of Financial Fragility}

\begin{tabular}{|c|c|c|c|c|}
\hline & & & & \\
\hline & Probit & Dy/dx & Probit & $\mathrm{Dy} / \mathrm{dx}$ \\
\hline Age & -0.017 & -0.005 & -0.016 & -0.004 \\
\hline & $(0.018)$ & $(0.005)$ & $(0.018)$ & $(0.005)$ \\
\hline Married & -0.018 & -0.005 & -0.018 & -0.005 \\
\hline & $(0.072)$ & $(0.020)$ & $(0.073)$ & $(0.020)$ \\
\hline White & $-0.319 * * *$ & $-0.090 * * *$ & $-0.276 * * *$ & $-0.077 * * *$ \\
\hline & $(0.074)$ & $(0.021)$ & $(0.075)$ & $(0.021)$ \\
\hline Male & $-0.145^{* *}$ & $-0.041 * *$ & -0.075 & -0.021 \\
\hline & $(0.064)$ & $(0.018)$ & $(0.066)$ & $(0.018)$ \\
\hline Number of dependent Children & $0.075^{*}$ & $0.021^{*}$ & $0.073^{*}$ & $0.021^{*}$ \\
\hline & $(0.042)$ & $(0.012)$ & $(0.042)$ & $(0.012)$ \\
\hline Ed. High School & $-0.356 * * *$ & $-0.101 * * *$ & $-0.292 * *$ & $-0.082 * *$ \\
\hline & $(0.138)$ & (0.039) & $(0.139)$ & (0.039) \\
\hline Ed. Some College & $-0.385 * * *$ & $-0.109 * * *$ & $-0.277^{*}$ & $-0.078^{*}$ \\
\hline & $(0.141)$ & $(0.040)$ & $(0.143)$ & $(0.040)$ \\
\hline Ed. College or More & $-0.565^{* * *}$ & $-0.160 * * *$ & $-0.417 * * *$ & $-0.117 * * *$ \\
\hline & $(0.145)$ & $(0.041)$ & $(0.150)$ & $(0.042)$ \\
\hline Income \$15k-\$25k & $-0.412 * * *$ & $-0.116 * * *$ & $-0.395^{* * *}$ & $-0.111^{* * *}$ \\
\hline & $(0.121)$ & $(0.034)$ & $(0.122)$ & $(0.034)$ \\
\hline Income \$25k-\$35k & $-0.691 * * *$ & $-0.195^{* * *}$ & $-0.666 * * *$ & $-0.186^{* * *}$ \\
\hline & $(0.126)$ & $(0.035)$ & $(0.127)$ & $(0.035)$ \\
\hline Income $\$ 35 \mathrm{k}-\$ 50 \mathrm{k}$ & $-0.963 * * *$ & $-0.272 * * *$ & $-0.917 * * *$ & $-0.257 * * *$ \\
\hline & $(0.121)$ & $(0.032)$ & $(0.122)$ & $(0.032)$ \\
\hline Income $\$ 50 \mathrm{k}-\$ 75 \mathrm{k}$ & $-1.271 * * *$ & $-0.360 * * *$ & $-1.202 * * *$ & $-0.337 * * *$ \\
\hline & $(0.124)$ & $(0.032)$ & $(0.126)$ & $(0.033)$ \\
\hline Income $\$ 75 \mathrm{k}-\$ 100 \mathrm{k}$ & $-1.623 * * *$ & $-0.459 * * *$ & $-1.536 * * *$ & $-0.430^{* * *}$ \\
\hline & $(0.146)$ & $(0.037)$ & $(0.149)$ & $(0.038)$ \\
\hline Income $\$ 100 \mathrm{k}-\$ 150 \mathrm{k}$ & $-2.027 * * *$ & $-0.573 * * *$ & $-1.939 * * *$ & $-0.543 * * *$ \\
\hline & $(0.167)$ & $(0.042)$ & (0.169) & $(0.042)$ \\
\hline Income $>\$ 150 \mathrm{k}$ & $-2.099 * * *$ & $-0.594 * * *$ & $-2.003^{* * *}$ & $-0.561^{* * *}$ \\
\hline & $(0.203)$ & $(0.053)$ & $(0.202)$ & $(0.053)$ \\
\hline Income Shock & $0.450 * * *$ & $0.127 * * *$ & $0.458 * * *$ & $0.128 * * *$ \\
\hline & $(0.067)$ & $(0.018)$ & $(0.067)$ & (0.018) \\
\hline FinLit Index & & & $-0.111 * * *$ & $-0.031 * * *$ \\
\hline & & & $(0.027)$ & $(0.007)$ \\
\hline Constant & $2.192^{* *}$ & & $2.228^{* *}$ & \\
\hline & $(1.074)$ & & $(1.074)$ & \\
\hline Observations & 2,983 & 2,983 & 2,983 & 2,983 \\
\hline
\end{tabular}

Note: The sample includes all age-eligible individuals age 56-61 in the 2012 NCFS; estimates weighted using sample weights. The dependent variable is a dummy variable response to the following question: "How confident are you that you could come up with $\$ 2,000$ if an unexpected need arose within the next month?” Outcome coded as 1 for those certain or probably could not come up with $\$ 2,000$. Robust standard errors in parentheses.

*** $\mathrm{p}<0.01$, ** $\mathrm{p}<0.05$, * $\mathrm{p}<0.1$ 